\title{
The Balance between Exceptional Cases and the Risk of Fake: An Ever Present Theme
}

\author{
Maria Teresa Bianchi ${ }^{1}$ \\ ${ }^{1}$ Department of Law and Economics of Productive Activities, University of Rome La Sapienza, Italy \\ Correspondence: Maria Teresa Bianchi, Department of Law and Economics of Productive Activities, University \\ of Rome La Sapienza, Via del Castro Laurenziano 9, Rome, Italy. E-mail: mariateresa.bianchi@uniroma1.it
}

Received: November 19, 2017

Accepted: December 25, 2017

Online Published: January 22, 2018

doi:10.5539/ijbm.v13n2p245

URL: https://doi.org/10.5539/ijbm.v13n2p245

\begin{abstract}
Purpose: The purpose of this paper is to show that the false in the budget is due to false accounting and not false evaluation.

Design/methodology/approach: Research articles from the most relevant Italian and foreign journals, from the period when this phenomenon was studied by the doctrine, in favor of or against the reformed subject, to ensure a complete analysis of the case. Practical case refers to work experience from the author of the paper. The methodology used in the paper is that of qualitative analysis.
\end{abstract}

Originality: The author proposes this paper because on this reform most of the doctrine has expressed often divergent opinion and the author wanted to clarify the phenomenon.

Findings: The author demonstrates, by the case, that there are several ways to represent the business reality correctly and therefore that the false in the budget can be objectively present in the accounting and not in the valuation.

Keywords: Balance Sheet, false social communications, bank, IAS, OIC

\section{Introduction}

The aim of the document is to question the usefulness of reform implemented by the law n.69 on 27 May 2015 . In recent times, the competent bodies have planned a new legislation on the false reporting. The Law n.69 of 27 May 2015, introduced on 14 June 2015, has changed the legislation on the false reporting (legislative items 2621 and 2622 of Civil Law) and the legislation on the administrative responsibility of the bodies in relation to corporate crimes (legislative items 25-ter, subparagraph 1, Legislative Decree n.231, 8 June 2001). The same law introduced two new disciplines (legislative items 2621-bis c.c. and legislative items 2621 -ter c.c.).

Reason for reform is reactivate the false reporting because prohibits the free competition. The previous legislation introduced some limitations on false reporting (thresholds of non-punishment, procedural issues and causes of non-punishment) (Alessandri, 2001; Marinucci, 2001; Pedrazzi, 2001; Pulitanò, 2001; Belcredi, 2002; Conti L., 2002; Donini, 2002; Lozzi, 2002; Foffani, 2002; Paliero, 2002; Seminara, 2002). Today the new legislation seems to have an opposite meaning respect the present legislation (D'Alessandro, 2015; Gambardella, 2015; Mucciarelli, 2015; Ruta, 2015; Santoriello, 2015; Seminara, 2015; Masullo, 2016; Mezzetti, 2016; Strampelli, 2016) and consequently the subject of objective falsity contrasts with economic truth, and not with absolute truth.

The discussion paper shows extraordinary case and the exception, jurisprudence and doctrine rarely have studied these cases. It is the case with the highest subjectivity in the evaluation, resulting from the assumption of responsibility by the editors and the auditors of the reporting. In this paper to put under close scrutiny, from the business point of view, the new legislation, also it shows the case of the reporting of the extraordinary administrations of the four banks subject to the Bank of Italy's deliberation n. 1241014/15 of 21 November 2015 that provided for dissolution of them based on art. 32 of Legislative Decree n. 180/2015 and of the Bank of Italy provision n. 1241121/15 of November 22, 2015, which has determined the start of the effects. In light of the arguments presented in this section, the research questions are: RQ1: Can you set the false evaluation as false in the budget?? 
The article is structured as follows: After the introduction, the second part provides an analysis of the changes made by the reform both from the textual point of view and the doctrine, which is divided into authors who regard the fake as related to the evaluation and the authors who believe that the fake in the budget is objectively configurable in the accounting data. Section three contains the opinion of the Reformation Laws. Section four consists in the analysis of an operational case linked to the bankruptcy of the four banks, where it turns out that there may be different ways of assessing the same reality. Section five contains the conclusions that show that the presence of the false budget is before the drafting of the document, in the accounting data.

\section{The Legislation on the False Reporting}

The law n. 69/2015 has intensified the type of offense of false social communications, respect to the previous reform as decree n. 61/2002. The new clause 2621 of Civil Law order:

$<<$ Out of the cases provided for in article 2622, directors, general managers, executives responsible for preparing corporate accounting documents, statutory auditors and liquidators, who show material facts that are not in accordance with the law, or omit material facts that are subject to disclosure by the law of the economic, financial or financial situation of the company or group to which it belongs, in a concretely mislead other, in the budgets, in the report or in the other social communications direct to the shareholders or to the public, because they want to perceive unjust profit, the punishment five years of imprisonment. The same penalty applies even if falsehoods or omissions concern assets owned or administered by the company on behalf of third parties. $>>$

The fundamental differences compared to previous legislation are:

- Social communications previously constituted as criminal offenses and administrative offenses connect to a crime and are therefore punishable by imprisonment for one to five years instead of a term of up to two years;

- Insertion of the adverb consciously before "exposing material facts that are not true to the truth" is to indicate that there must be awareness, by the active person, in the display of "untrue facts" for criminal offense;

- The introduction of the relevant adjective related "material facts" highlighted the legislator's purpose of delimiting the criminal area relevant to the most serious;

- The adverb concretely before "able to mislead" does not include the conduct in the criminal profile, sure enough the modalities of deception must endanger the legal protection protected by the norm;

- The deletion of the phrase "still subject to evaluations" referring to material facts that are not true. This implies that false reporting of valuation would not be considered corporate crimes.

- According to the new legislation for the verification of the specific damage, it is sufficient to find an unfair profit for itself or for others. So, there is no need to deceive shareholders.

The doctrine (Donini, 2002; Foffani, 2002; D'Alessandro, 2015; Testaguzza, 2015; Gualtieri, 2016; Mezzetti, 2016) expressed on reform and the judgment is negative, the most important criticism referring to the new Article 2621 is that if you wanted to eliminate discretion in the judge's judgment by deleting the phrase "even though subject to evaluations", the result is far from the objective. Indeed, the introduction of the term "relevant" in relation to "material facts" implies a judge's assessment, on a case-by-case basis, of whether or not material facts (Cass., Sec V, 16 June 2015).

At this point, we need to understand what material facts are not true. There is no unambiguous answer, however, doctrine and practice (Perini, 2015) have over the years listed such cases. In particular, they are certainly regarded as "material facts not true":

- Disclose in the reporting of non-real revenue or non-real costs (exemplified those resulting from false documents);

- Disclose in the reporting of definitively unpayable or non-existent or unrealizable credits or other reporting items;

- Omit the sale or purchase of goods;

- Don't devalue the value of shares despite the bankruptcy of subsidiary;

- Don’t disclose a debt connected to losing parties;

- Indicate non-existent credits as they originate from bogus contracts;

- Indicate in the assets of the Balance Sheet the credit to a customer for "invoices to be issued" in violation of the accrual basis. 
- Indicate the amount of loans and advances to customers in relation to the issue of an invoice for non-existent transactions.

The previous list provides important ideas: the first is that the cases listed are all attributable to events originated at the beginning of the budget process and, therefore, false accounting records even before the budget (Viganò, 1990; Bianchi, 1998; Bianchi, 2006). In fact, the previous list doesn't include incorrect evaluation or estimates. On this point, we will return later.

The new legislation also applies to art. 2621 bis and ter. The ratio of art. 2621 bis are to punish with minor rigor the events of a mild severity. While article 2621 ter provides that, for the purpose of non-punishment for a particular tenuity of the facts, the court must primarily assess the extent of the harm caused to the company, its members or creditors as a result of the facts referred to in article 2621 and 2621-bis. While article 2621b provides that, for the purpose of non-punishment for a particular tenuity of the facts, the judge will carefully assess the extent of the damage caused to the company, shareholders or creditors resulting from the facts referred to in articles 2621 and 2621-bis.

The main criticisms of the articles cited refer to the concept of minor offenses, indeed, the letter legis appears rather vague and does not allow an objective evaluation of minor offenses (Testaguzza, 2015; Manes, 2016). In addition, it is considered paradoxical that, for non-punishment, the judge should assess the possible damage, while for the assessment of the actual danger of a crime provided for in article 2622 Civil Law that element is indifferent to the implementation of the case. The new article 2622 Civil Law provides:

$<$ Directors, directors general, directors working on the preparation of the accounting documents, statutory auditors and liquidators of issuing companies financial instruments admitted to trading on an Italian or other regulated European market that exhibit material facts that are not true in the financial statements, reports or other corporate communications addressed to shareholders or the public or they omit material facts whose disclosure is imposed by the law on the economic, financial or financial situation of the companies or groups to which it belongs, so as to cause others in error, they are punished with the imprisonment sentence of three to eight years.

The companies listed in the preceding paragraph equate to:

- $\quad$ Companies issuing of financial instruments for which an application for admission to trading on an Italian regulated market or another country of the European Union has been submitted;

- $\quad$ Companies issuing financial instruments admitted to trading in a multilateral trading system in Italy;

- Companies controlling companies' issuers of financial instruments admitted to trading on a regulated Italian or other European Union country;

- $\quad$ Companies that offer public saving or which they still manage.

The provisions of the preceding paragraphs shall apply even if the omissions or omissions pertain to assets owned or administered by the company on behalf of third parties. >>

The differences with the previous article are:

- Conversion of the offense from crime to crime and consequent tightening of the sentence ranging from imprisonment, from six months to three years to imprisonment from three to eight years in the "new" article;

- Indication, in the second paragraph, of the new wording of article 2622 of the companies equivalent to those provided for in the first paragraph;

- Elimination of the event (damage) and the thresholds provided for in the previous version of Article 2622.

The Law of 27 May 2015 amended article 25b of Legislative Decree 231/2000; in particular, the reference to the company's interest in the commission of corporate crimes has been eliminated. In addition, a paragraph referring to the newly emanating article 2621-bis has been added. The sanctions were tightened.

In summary, why the offense of false social communications is to be configured is sufficient that the behaviors of the active parties, that is, of those involved in the budget process, are characterized by the desire to achieve unjust profit (understood as utility and non-monetary) their own advantage and to the benefit of other potential partners, such as the same company.

The legislation mentioned has raised criticism both in the legal and economic context. In particular, the National Accountants Foundation (De Vivo \& Gallucci, 2015) decided that the new legislation is unclear as the interest in transparency, correctness and completeness of corporate information constitute the legal asset protection. It would have been appropriate to exclude, with reference to the qualifying elements of the offense, any possible 
damage, in order to avoid the danger of enlargement to the extent of the scope of the rule, in order to achieve the objective mentioned above. Further doubts are related to the use of the adverb "consciously", since the use of the "intentionally" adverb, used in the previous version, would best be configured for the constituent elements of the case, namely the intention to provide unrealistic social information, to deceive and unjustly profit from the harmful event.

As regards the objective element of the offense, the CNDCEC considered it appropriate to delimit the perimeter within which to specify the concept of "false budget", calling for the national accounting principles prepared by the Italian Accounting Organization (OIC) and International Accounting Standards (IAS / IFRS) as appropriate criteria, both qualitatively and quantitatively, to determine whether the preparation of financial statements is correct or not.

Finally, the CNDCEC suggests that it also assesses the possibility of reintroducing quantitative thresholds, without prejudice to the need for their identification by carrying out an economic-statistical analysis of the Italian business system. Thus, it must be emphasized that "material facts" cannot include, for conceptual reasons, the kind of assessments.

\section{The Jurisprudence on False Reporting}

The jurisprudence intends to further tighten issue of falsity, as reported in Judgment $\mathrm{n} .7$ of the Supreme Court on 31 March 2016. The Supreme College has expressed the possibility that configure the false social communication was the inclusion in the budget of a "shareholders anticipation" account. Indeed, the Court has asked whether, on the subject of false social communications, the amendment by which Article 9 of Law N.67 of 27 May 2015, has canceled in art. 2621 C.l. The phrase "even though subject to assessment" has resulted in a partial abrogation of the case, or if that effect has not occurred. In summary, it is possible to configure false communication when evaluating.

Previous judgments of the Courts of Merit (Cass., Sec. V, 16 June 2015, N..33774, Cass., Sec. V, 12 November 2015, Cass., Sec. V, 8 January 2016, Sect V, March 30, 2016, N. 12793) had been antithetical to one another; Therefore, the supreme court ruling is the true interpretation of the rule.

The Chambers of the Court of Cassation has tackled the problem in a systematic way, the Chambers of the Court of Cassation faced the problem in a systematic way, through an organic and tendentiously consistent and coherent view of the entire corporate matter on the budget and the sub-system of criminal law to protect the proper formulation of the document, assuming that the object of protection is to be identified in "corporate transparency". The judgment may be summarized as follows:

- From article 2423 Civil Law to 2427 Civil Law the legislator is not only obliged to indicate the structure and content of the budget, but indicates the accounting policies and imposes assessment fees and indicates what the supplementary note should contain. The budget is a document with essentially evaluative content, a document that converges relevant data, estimated data and conjectural data. The budget is a composite and complex document, whose reading requires a specific preparation, which includes knowledge of the criteria (both legal and technical) in force for its editorial staff. In addition, the editor of this document must conduct "guided" evaluations from the mandatory and largely shared criteria established by the national legislator and the national directives. In fact, the manager in charge of drafting must make a weighting of the individual components of the budget by assigning a cash value to each of them. In summary, all civil law presupposes the valuation time in the drafting of the financial statements by outlining a conventional valuation method (ex. amortization, depreciation, claims, equity investments, development costs, etc.). In addition, it is also envisaged that the editor may, in exceptional cases, deviate from the criteria set by law if they can be a hindrance to a true exposure to information, that derogation must be fully explained in the explanatory note. So, don't consider false valuation as a crime would mean:

- Excessively limit the application of articles 2621Civil Law and 2622 Civil Law;

- $\quad$ "Sterilize" the budget with reference to its valuation content, denying its function, distorting its nature.

As for the comparison with article 2638 Civil Law, for this article also the phrase "the conduct of the active subject that exhibits material facts that do not correspond to the truth, even though subject to assessment", was an examination of the Court of Legitimacy but did not doubt of the validity of that term (Mangiapane Judgment of 28/09/2005). This means that any deletion from article 2638 of that expression did not modify the configuration of the rule. This means that if we consider the comparison to be correct, we can consider the superfluity of the disappearance of that sentence from the text of art. 2621 and 2622 of the Civil Law.

As for the parallel with tax law, according to authoritative doctrine, for years now this approach has lost 
meaning.

In the jurisprudential view of legitimacy, the figure of false valuation is firmly incardinated and its boundaries (as well as its content) is sufficiently traced. The case law of the Supreme Court, and in particular that of the Fifth Criminal Division, has already made it clear that it is certainly possible to conceive the falsehood of valuation enunciations both in terms of false ideological and in the case of false evidence.

Already in the past (judgment n.3552, Andronico of 1999), an equation was made between the falsehood of a valuation statement based on false premise and the falseness of a statement (likewise evaluative) that is in open contradiction with undisputed and indisputable criteria of evaluation. This ruling was confirmed by recent judgments (n.51825 of 25/09/2015 and n.39843 of 04/08/2015).

Lastly, it is argued that accounting is certainly a category of science with a low margin of discretion; hence the "valuation" of the fact that is fake invests their "materiality". This without ignoring the fact that most of the valuation parameters are established by law. It follows that the drafting of the financial statements is certainly a syndication activity also with reference to its valuation moment; and this is precisely because such assessments are not "free" but are legally and/or technically binding.

In conclusion, it is possible to argue that the false valuation keeps its criminal record, it will then be for the judge to conduct an assessment of the decision's potential of the false information contained in the budget and ultimately to express a judgment on the suitability of the artifices and scams contained in the aforementioned Accounting document, in view of a potential induced error in incertam personam.

Without failing to respect the Supreme College, it is undeniable that accounting science conceives the process of budgeting as an evaluation process that provides a continuity of a reality (business management) (Onida, 1951; Amaduzzi, 1957; Einaudi, 1959, Viganò, 1990; Superti Furga, 1991; Bastia, 1993; Bianchi, 1998; Capaldo, 1998; Bianchi, 2006; Georgiou, 2011), which has no continuity. Therefore, it is the result of a forcing. The issue is that, as confirmed by the Court, the evaluation must comply with the prescribed rules and give proper qualitative information, but the Court forgets that the correctness of the operation are often linked to alternatives that are all different and compatible with one purpose only to emerge the economic truth of the budget (Einaudi, 1959; Bianchi, 1998; Capaldo, 1998; Bianchi, 2006).

Then, re-opening the subject of false-budget assessment appears to be anachronistic, false is absolute when it is objectively done in accounting and not when it comes to choosing among possible alternatives (Bricchetti, 2015; Lanzi, 2015; Caraccioli, 2015; D'Avirro, 2015; Perini, 2015; Pistorelli, 2015; Scoletta, 2015; Superti Furga, 2015; Testaguzza, 2015).

In order to clarify this, it is emblematic to expose what happened in the case of the extraordinary governments' financial statements of the four banks c.d. Bail In (Rutledge; Moore; Dobler; Bossu; Jassaud; Zhou, 2011).

\section{The Operating Cases of the Extraordinary Accounts of the Four Banks Subject to the Bail in}

Before explaining the technical issue of the closure of an Extraordinary Administration procedure under the Single Banking Act, it is necessary to explain the specific case.

On November 16, 2015, the Italian Parliament approved legislative decree n.180, incorporating the Bank Recovery and Resolution Directive (Speyer \& Böttche 2013; Labrosse et al., 2014) into national law, and Legislative Decree n.181 for the consequent modification and integration of the TUB.

On November 18, 2015, the Bank of Italy established the National Banking Resolution Fund for Banks in Italy, 78 of the new legislation.

At that time, in Italy, there were four banks in the Extraordinary Administration who were in a crisis situation so that they could not find a solution that would allow their salvation. Consequently, in the absence of appropriate measures to resolve the crisis and the severity of the situation, the Bank of Italy, in its capacity as Resolution authority, carried out the provisional assessment provided for in the urgency of paragraph 2 of art. 25 of Legislative Decree 180/2015, in order to determine the weight of the bad debts and to quantify an asset that could allow the new bank to remain on the market.

On 21 and 22 November 2015, the Bank of Italy adopted a series of measures, approved by decree of the Minister of Economy and Finance on 22 November 2015, initiating the resolution of People's Bank of Etruria and People's Bank of Lazio, Savings Bank of Ferrara, the Bank of Marche and the Savings Bank of the Province of Chieti through Article 32 of Legislative Decree 180/2015 in the Framework of an articulated operational and time program.

The transaction resulted in the closure of extraordinary management procedures and the subsequent transfer to 
companies at 22:00 on 22 November 2015 to the respective banks' organs at a resolution appointed by the Bank of Italy.

The existence of the grounds of urgency (Article 25, paragraph 1, Legislative Decree 180/2015), the initiation of the resolution and the other accompanying measures was carried out on the basis of a provisional assessment by the Bank of Italy (Article 25, paragraph 2) referring to the principles contained in the EBA Regulatory Technical Standard. This provisional valuation, based on the accounting situation at the end of September 2015, having taken into account the Bank's forecasts on the economic performance until the start of the resolution (Step One), has provided for the assessment of the non-performing loans intended to be transferred from the Bridge Institution to a specially formed "Bad Bank", on the basis of the expected market prices rather than the values consistent with ordinary accounting practices, and a prudent buffer for additional losses in accordance with in paragraph 2 of Article 25 of Legislative Decree 180/2015 (Step Two).

On the basis of this assessment, the Bank of Italy has placed against the four banks the full reduction of reserves and capital and the nominal value of Class 2 items (These are capital instruments and subordinated loans), which can be linked to own funds (even for the unrelated part of the capital regulatory), with the consequent extinction of the related administrative and asset rights.

The provisions were accompanied by the Decree Law n. 183 of 22 November 2015 instituting pursuant to art. 42 of Legislative Decree 180/2015, with effect from 23 November 2015, the Bridging Bodies: New People's Bank of Etruria and Latium, New Savings Bank of Ferrara, New Bank of Marche, New Savings Bank of Chieti with a capital asset that guarantees the continuation of banking activity and is entirely owned by the Resolution Fund.

On the basis of the Bank of Italia's Measures on November 22, 2015, the four new Good Banks became transferee of all the rights, assets and liabilities that constituted the Banking company of bank in the resolution, including real property rights Real estate, contractual relations and the active and passive judgments pursuant to art. 43 and 47 of Legislative Decree n. 180/2015 with effect from 00:01 on the next day (Lener, 2016; Rulli, 2015).

According to art. 43, paragraph 4, of Legislative Decree n. 180/2015, the new Good Banks have been replaced, seamlessly, by Banks in resolving outstanding rights, assets, liabilities, reports and judgments.

Resolutions have been taken to ensure the operational continuity of banks in crisis, collected savings in the form of deposits, current accounts and ordinary bonds have been saved, workers have been protected, no public resources have been spent, public resources have not been used. The initiation of the resolution avoided the creditor's Bail-In, mandatory since 1 January 2016, and the prospect of "atomistic" liquidation.

The issue here is not how the BRRD (Bank Recovery and Resolution Directive, Directive 2014/59 / EU) is implemented, but the accounting impact that it has generated on the closure of Extraordinary Administration procedures.

In fact, in view of the briefly mentioned situation and knowing that the reporting of an Extraordinary Administration should be prepared in accordance with international accounting standards, pursuant to art. 75, paragraph 2 of Legislative Decree 385 of 1 September 1993 (TUB). In particular, the financial statements will comply with International Accounting Standards (IAS) and International Financial Reporting Standards (IFRS) issued by the International Accounting Standards Board (IASB) and related interpretations of the International Financial Reporting Interpretations Committee (IFRIC), endorsed by the European Commission and in force at the reporting date.

The application of the IFRS will also be made with reference to the "framework for the preparation and presentation of the budget" (cd Framework), with particular reference to the fundamental principle of the substance prevalence of form, and the concept of relevance and significance of information. In addition to the instructions contained in the Circular of the Bank of Italy n. 262 of December 22, 2005 "banking accounts: Schemas and Compilation Rules" and subsequent updates, account must be taken of the interpretations prepared by the Italian Accounting Organization (O.I.C.).

The most important issue concerns the principle of business continuity. In fact, from the point of view of international principles, continuity exists if it is possible to hypothesize, through a business plan, that the activity continues at least for the next 12 months. As has been clarified, the extraordinary administrations find their conclusion on the night of November 22, at the same time, however, all reports pass to the institutions in resolution and then to the bridge institutions. So, in fact, the operations continue in Good Banks. Another particularly complicated theme is the value of bad claims. Such packages, under the IAS, should be valued at their fair value, but in the present case, these credits have been valued at a "price" determined on the basis of a 
provisional valuation by the Resolution Authority on the basis of the company's accounting records September 30, 2015. This means that the value of these assets is the result of an administrative act on which the Extraordinary Administrations have not performed any independent valuation.

Therefore, the present case is entirely peculiar: it is an IAS compliant budget that must take into account a situation that is absolutely out of the ordinary; a situation that can be configured as an exceptional case. Exceptionality is represented by the administrative measure that closed the Extraordinary Administration, determined the value of the non-performing loans and had effects on the entities arising after the closing of the old banks.

The only thing that matters is the way the Extraordinary Administration budget closes. In fact, it is necessary to understand what valuations have been made in applying the accounting principles to take account of the particular situation as a result of the measures issued between 21 and 22 November 2015. International Accounting Standards do not clearly govern the accounting policies to be adopted in a situation of loss of the business continuity requirement but of the continuity of operational continuity.

We can hypothesize several accounting scenarios to apply to the concrete case, which will be analyzed below.

\section{1) Application of IAS 1, par. 19.}

The type of case determined as a result of the resolution could constitute the presence of one of the extremely rare circumstance provided by IAS n. 1 (Bischof \& Molzahn, 2007; Iatridis \& Valahi, 2010, Pellens et al., 2017), paragraph 19, which requires that IAS / IFRS be rejected, the application of which would produce misleading disclosures in relation to the purpose of the financial statements to represent the results of the activities attributable to the management choices of the Bank's Corporate Bodies.

The Financial Statements, therefore, would be IAS compliant in its entirety except for:

1) the result of the provisional assessment contained in the Supervisory Authority's measures, of the non-performing market prices and of the prudential buffer for additional losses;

2) the full reduction of reserves, of share capital and of Class 2 items, which can be linked to own funds (also for the part not included in the regulatory capital), resulting in the extinction of the related rights;

3) the sale, with effect from 00:01 on the next day, of all rights, assets and liabilities forming part of the banking company, including real rights on movable and immovable property, contractual relations and judgments on assets and liabilities Art. 43 and 47 of Legislative Decree n. 180/2015, to the institutional-bridge;

4) the sale of bad claims to bad banks, with effect from 1 February 2016, for a provisional consideration determined in accordance with the valuation carried out by the Bank of Italy pursuant to art. 25, paragraphs 1 and 2 of Legislative Decree 180/2015.

The following exceptions involve the disapproval of the following accounting principles:

- IFRS 5 (Zülch; Lienau, 2004) and IAS 39 (Fiechter 2011; Taylor; Goodhart, 2006; Walton 2004;) and Circular $262 / 2005$ on the classification and valuation of discontinued assets and liabilities assets, which include the disclosure of the assets to be sold and the associated liabilities in specific items Active and passive, respectively items 140 and 90, at the lower of the book value and their fair value, which coincides with the realization or extinction, and the exposure to the income statement of the results of those assets and liabilities in item 280 "Profit (Loss) disposal net of taxes".

- IAS 10 on significant events occurring after the closing date of the financial statements.

\section{2) Application of the OIC 5}

The Exceptionality and absolute newness of the Resolution could also configure the possibility of applying other editorial criteria.

In particular, according to the principle of the prevalence of the substance on form (Laghi, 2012) and the relevance and significance of the information, it is necessary to point out the moment in which business continuity is lost. In fact, AS banks have been shut down since in fact, there is no business continuity. This emerges from the application of IAS1 paragraphs 25 and 26. In the silence of the IAS / IFRS on the valuation criteria to be applied in this particular case, reference should be made to the guidelines established by the OIC, and in particular in Operations Guide n. 5 on May 2010.

In the particular circumstance, it may be considered to fall in the case of the operating instructions referred to in paragraph 6.4.2; according to which the commissioner's period is a period that can lead to a cause of dissolution, but that the real period of resolution (and then liquidation) is only later and dictated by the commencement of the 
formal administrative resolution / liquidation.

This interpretation determines that an account should not be taken off:

- the resolution initiating the measure and the provisional assessment contained therein, for the stage of assessing the non-performing loans at the expected market prices and the prudent buffer for additional losses;

- the measure, which has provided for the full reduction of reserves, share capital and Class 2 items, which can be accounted for in own funds (also for the part not included in the regulatory capital), with the consequent extinction of the relevant rights;

- of the provision which ordered the sale of all rights, assets and liabilities constituting bank resolution companies, including real rights on movable and immovable property, contractual relationships and active and passive judgments pursuant to art. 42 and 47 of Legislative Decree 180/2015, to the newly formed entities (Good Banks);

- of the provision for the sale of Good Bank's bad claims to Bad Bank pursuant to art. 25, paragraphs 1 and 2 of Legislative Decree 180/2015.

These events can be qualified as events subsequent to the end of the Extraordinary Administration procedure that do not involve any adjustments.

The transition from the banks to the Extraordinary Administration and the successive entities took place in a very short time span, safeguarding all the active relationships and most of the liabilities, the banks into extraordinary administration are considered by operating criteria, thus allowing to represent the actual trend of the ordinary and subordinated management of the period.

In essence, it is believed that continuity persists operationally even though the decoction state is such as to render the company away. However, the same goes on in its operation and, in fact, guarantees continuity over successive entities.

\section{3) Application of IAS 37}

An additional interpretation of the present case could be, however, to include the effects of the resolution in the closure of the Extraordinary Administration procedure in accordance with IAS 37 (Rees 2006, Fischer 2010). In particular, the principle of the application reflects the effects of the sale to the entity of the assets and liabilities of the banking company on the basis of the results of the provisional assessment provided for in the resolution initiated by the Bank in Administration extraordinary. In that interpretation, the transfer is not to be considered as an event subsequent to the close of the Extraordinary Administration - which is surely a factual and legal point of view - and the negative effect arising from the sale of the assets and liabilities included in the company Bank subject to transfer to the bridge institutions.

The beginning of the resolution plan, pursuant to the above application of international accounting standards, is emerging as an event with legal effect after the balance sheet date (22:00 hours of 22 November 2015), but resulting from a series of laws and regulations binding administration issued before the extraordinary closing, and, in particular:

- the resolution program of 21 November 2015, which established the resolution of the four Extraordinary Banks;

- the provisional assessment (contained in one of the resolution provisions) prepared by the Bank of Italy, referring to the principles contained in the Regulatory Technical Standard EBA on the Ex-art 36 evaluation of the BRRD;

- of the Decree Law of 22 November 2015, n. 183, which constituted the four new Good Banks in order to implement the resolution program;

- of the Measures of November 22, 2015 that have disposed of, with effect from 00:01 on the next day, all rights, assets and liabilities constituting the banks of the four Banks in the resolution, including real property rights Mobile and real estate, contractual relations and judgments active and passive under art. 43 and 47 of Legislative Decree n. 180/2015, to the newly formed entities bridge (Good Banks) to a negative value determined on the basis of the provisional valuation.

The interpretation described follows from IAS 37, which requires accounting for a provision if "an enterprise has an ongoing obligation (legal or implied) as a result of a past event; It is probable (it is more likely than the opposite) that in order to fulfill the obligation, the use of resources to produce economic benefits will be necessary; and a reliable estimate of the amount resulting from the fulfillment of the obligation may be made. " 
These requirements, which, in the specific situation of the resolution, already apply to the extraordinary administration's closure budget, since the resolution measures were issued by the competent authorities prior to the closure of the extraordinary administration procedure.

No account is taken of the effects of the provision which, in its resolution, has provided for a complete reduction of reserves, share capital and Class 2 elements that can be accounted for in own funds (also for the part not included in regulatory capital), resulting in the extinction of Related administrative and capital rights, excluding the sale to the bridge institutions. With reference to the computable subordinated debt (subject to the reduction provision) and the uncollectable subordinated debt, it is stated that, under International Financial Reporting Standards, a financial liability can be canceled from the financial statements only when the obligation expires legally, In the present case, that extinction took place only after the date of closure of the Extraordinary Administration.

Consequently, in accordance with the International Accounting Standards, and in particular in compliance with IAS 37, it will have to write down a statement of income in the income statement for the year, which is the provision of a provision for risks and charges. The amount of this fund is determined as the difference between the net carrying amount of assets and liabilities subject to disposal valued according to operating criteria and the debt arising from the resolution of the bank following the sale of assets and liabilities to Good Banks.

Three interpretations for the same budget. What is true? None! Because the budget is not true in the absolute sense it is true in the economic sense, in fact, it must be able to represent corporate events in a clear, correct and transparent manner and should not conceal potential liabilities or include non-existent activities. The budget is not built by pushing a button, the budget is the result of a complex evaluation work that must account for the company's economic / financial performance. As the case shows, the guidelines are not always clear, exhaustive and unambiguous. In such situations, the manager who draws the budget has only the option of choosing a road and explaining clearly the reasons for his choices; these must fall within the provisions of law and operating rules. In addition, both the first (Article 2423 C.L.) and the second (IAS 1 paragraph 10) clarify that in the presence of exceptional situations, not foreseeable by abstract and general schemes, the most adherent representation of the concrete case must be provided, even in derogation of the rules themselves.

Therefore, in this case the application of IAS 1 par. 10 would appear to be the most consistent with a case never before recorded and probably not replicable in the same way in the future. But the application of OIC 5 has its own ratio, the situation that has been created is such that it constitutes the previous phase of liquidation. The last interpretation is the one that cautiously warns the manager who draws up the budget and also the controllers of the same because the creation of a risk fund already in the balance sheet of the Extraordinary Administration seems more cautious than the other two versions.

No one can say that the budget is truer, it can be more cautious, more precautionary, but no truer. Among other things, the quantitative impacts between the first and second versions are almost null, the third version, with the creation of the risk fund, has a greater impact, but not so much to distort the trend of the budget.

Hence, the theme of evaluation is not a theme that invalidates the truth, but the building itself of the budget. Falsification must be sought in accounting, in choosing to construct a false representation that must have accounting support in order to be credible.

\section{Conclusive Considerations and Future Research}

The above discussion, though in its clear synthesis, aims to highlight how dangerous it is to enter into the merit of the fake in a construction process such as that of the budget based on subjectivity.

The theme appeared, until reform, closed; In fact, surpassed by the so-called thresholds. However, from the economic point of view, the concept is much deeper. Searching for falsehood in evaluation is a no-sense, especially when the manager who draws up the budget clarifies how he worked and why he did so. In the preceding hypotheses, where it would be false, these are interpretations, all reasonable and applicable to the concrete case.

False communication is something very different, is the failure to record costs / revenues incurred, or the inclusion of unearned / unearned costs or revenues. False is the masking of reality and must necessarily start from accounting; while evaluation is a choice that does not necessarily, as seen, inflicts quantitative information but only of qualitative information. It is very dangerous to search for falseness in evaluation choices, because this could jeopardize the correctness of the manager who draws the budget, in the sense that two possible choices will be sought for the one that will find the placet of controllers more easily, even if it is not the one able to represent the economic truth. 
The case of the four banks is obvious that it involves special reasons, exceptional cases, and would therefore be the most natural choice, and yet here is defined as a more conservative choice, but from the information point of view probably less suitable to represent all the exceptionality Of the concrete case.

The fraudulent fiscal policies that distort the representation of the economic truth of the budget (Onida, 1951; Viganò, 1990; Superti Furga, 1991; Bastia, 1993; Bianchi, 1998; Capaldo, 1998; Bianchi, 2006) Do not break through trying to locate falsehood in the evaluation. Whatever the principle to follow, in fact, is the manager who draws up the budget that must be corrected (Bianchi, 2006) and make choices in line with the budget building guidelines, always motivating them. If the budget is intended to conceal potential losses, or not to show revenue, no accounting standard will be able to prevent it, nor will there be a false accounting rule.

\section{References}

Alessandri, A. (2001). La legge delega n.366 del 2001: un congedo dal diritto penale societario. Corr.giur., n.12.

Amaduzzi, A. (1957). Conflitto ed equilibrio di interessi nel bilancio dell'impresa. Cacucci, Bari.

Bastia, P. (1993). Il nuovo bilancio di esercizio: attuazione della IV Direttiva Cee. CLUEB; Bologna.

Belcredi, M. (2002). A rebours, ovvero: la riforma del falso in bilancio. In Mercato concorrenza Regole.

Bianchi, C. (1998). Scritti in materia di bilancio d'esercizio. Kappa, Roma.

Bianchi, C. (2006). IAS/IFRS, US GAAP, Principi Contabili Nazionali, Normativa Codificata: Confronto ed Analisi. Esculapio, Bologna.

Bianchi, M. T. (2006). La trasparenza dei bilanci e criteri di valutazione. Rivista dei Dottori Commercialisti di Roma Telos, Roma.

Bischof, S., \& Molzahn, S. (2007). Ias 1 (revised 2007), "Presentation of Financial Statements”, IRZ.

Bossu, W., Dobler, M., Jassaud, N., Moore, M., Rutledge, V., \& Zhou, J. (2012). From Bail - out to Bail in: mandatory debt restructuring of Systemic Financial Institutions. international monetary fund 3/2012.

Bricchetti, R., \& Pistorelli, L. (2015). La lenta "scomparsa" del diritto penale societario italiano. Guida al diritto n. 26.

Capaldo, P. (1980). Gli obiettivi del bilancio d'esercizio e la IV direttiva CEE, La contabilità delle imprese e la IV direttiva. Etas, Milano.

Capaldo, P. (1998). Reddito, Capitale e Bilancio. Una introduzione. Giuffrè, Milano.

Caraccioli, I. (2015). Il rischio penale per le valutazioni estimative: reati fiscali a confronto col nuovo falso in bilancio. Fisco n.28.

Conti, L. (2002). La riforma dei reati societari: ovvero della licenza nella contabilità delle imprese. In Riv. trim. dir. pen. ec., CEDAM, Padova.

D’Alessandro, F. (2015). La riforma delle false comunicazioni sociali al vaglio del giudice di legittimità: davvero penalmente irrilevanti le valutazioni mendaci? giurisprudenza italiana, 2015.

De Vivo, A., \& Gallucci, M. (2015). La nuova disciplina del falso in bilancio. Fattispecie, applicabilità, riflessi sulla responsabilità degli enti. Fondazione Nazionale dei Commercialisti.

Donini, M. (2002). Abolitio criminis e nuovo falso in bilancio. Struttura e offensività delle false comunicazioni sociali (artt. 2621 e 2622 cc.). dopo il d.lg. 11 aprile 2002, n.61, Cass. Pen.

Einaudi, L. (1959). Miti e paradossi della giustizia tributaria. Einaudi Editori, Torino.

Fiechter, P. (2011). The effects of the Fair Value option under IAS 39 on the Volatility of Bank Earnings. Journal of International Accounting Research, 10.

Fischer, D. (2010). Der Standardentwurf, "measurement of liabilities in IAS 37 (ED/2010/1). In PIR 2010;

Foffani L. (2002). La nuova disciplina delle false comunicazioni sociali (aett.2621 e 2622), in AA.VV, "I nuovi reati societari: diritto e processo. a cura di Giarda-Seminara, CEDAM, Padova.

Gambardella, M. (2015). Il ritorno del delitto di false comunicazioni sociali: tra fatti materiali rilevanti, fatti di lieve entità e fatti di particolare tenuità, Cass. pen.

Georgiou O., \& Jack, L. (2011). In pursuit of legitimacy: a history behind fair value accounting. The British Accounting Review, 43(4).

Gualtieri, P. (2016). Le nuove false comunicazioni sociali: il punto di vista aziendale. rivista di diritto penale 
contemporaneo.

Iatridis, G., \& Valahi, S. (2010). Voluntary. IAS1 accounting disclosures prior to official IAS adoption: An empirical investigation of UK firms. Research in International Business and Finance, 24(1).

Labrosse, J. R., Olivares, C. R., \& Singh, D. (2014). The EU bank recovery and resolution directive - some observations on the financing arrangements. Journal of Banking Regulation, 15.

Laghi, E. (2012). L'avviamento nella disciplina del Codice Civile e dei Principi Contabili Nazionali e nel sistema IAS/IFRS: brevi considerazioni critiche. In L'Avviamento nel diritto Tributario, a cura di E. Della Valle, V. Ficari, G.Marini, Giappichelli, Torino.

Lanzi, M. (2015). Quale strano scopo del falso in bilancio che torna reato. Guida al dir. n.26.

Lener, R. (2016). Bail-in bancario e depositi bancari fra le procedure concorsuali e regole di collocamento degli strumenti finanziari. Banca borsa e titoli di credito, Giuffrè, Milano.

Lozzi, G. (2002). Successione di leggi e riforma dei reati societari. R. it. d. proc. pen..

Marinucci, G. (2001). Falso in bilancio: con la nuova legge avviata una depenalizzazione di fatto. In Guida dir. n. 45.

Masullo, M. N. (2016). Falso in bilancio e valutazioni punibili? Altri e non meno rilevanti interrogativi. rivista di diritto penale contemporaneo.

Mezzetti, E. (2016). La ricomposizione disarticolata del falso in bilancio (commento agli artt. 9-12 della 1. $\mathrm{n}$. $69 / 2015)$.

Mucciarelli, F. (2015). Le nuove false comunicazioni sociali: note in ordine sparso. rivista di diritto penale contemporaneo.

Onida, P. (1951). Il bilancio d'esercizio nelle imprese. Significato economico del bilancio. Problemi di valutazione. Giuffrè, Milano.

Paliero, C. E. (2002). Nasce il sistema delle soglie quantitative: pronto l'argine alle incriminazioni. Guida al dir. n.16.

Pedrazzi, C. (2001). In memoria del falso in bilancio. Riv. soc.

Pellens, B., Fülbier, R. U., Gassen, J., \& Sellhorn, T. (2017). Internationale Rechnungslegung: IFRS 1 bis 16, IAS 1 bis 41, IFRIC - interpretationen, Standardentwürfe. 10. Auflage, Schäffer - Poeschel.

Perini, A. (2015). I fatti materiali non rispondenti al vero: harakiri del futuribile falso in bilancio? Rivista di diritto penale contemporaneo.

Pulitanò, D. (2001). Falso in bilancio: arretrare sui principi non contribuisce al libero mercato. Guida al dir. n. 45.

Rees, H. (2006). The IASB's Proposed Amendments to IAS 37. Accouting in Europe, 3.

Rulli E. (2015). Prevenire l'insolvenza. Dal salvataggio pubblico alla risoluzione bancaria: rapporti con $i$ principi della concorsualità e prime esperienze applicative, Riv.trim. dir. Economia n. 4.

Ruta G. (2015). Problemi interpretativi intorno al nuovo falso in bilancio. La responsabilità amministrativa delle società e degli enti, Rivista 231 n. 4.

Santoriello, C. (2015). Rilevanza penale della valutazione in bilancio. Poche parole per riportare ordine in un dibattito "isterico". Arch. Pen. n. 2.

Scoletta, M. (2015). Tutela dell'informazione societaria e vincoli di legalità nei nuovi delitti di false comunicazioni sociali. Le società n. 11.

Seminara, S. (2002). False comunicazioni sociali, falso in prospetto e nella revisione contabile e ostacolo alle funzioni delle autorità di vigilanza. Riv.it dir. pen. proc..

Seminara, S. (2015). False comunicazioni sociali e false valutazioni in bilancio: il difficile esordio di una riforma. Riv.it. dir. proc. Pen..

Speyer, B. (2013). EU Banking Union, right idea, poor execution. DB Research.

Strampelli, G. (2016). Sulla (persistente) rilevanza delle valutazioni di bilancio: appunti interdisciplinari, rivista di diritto penale contemporaneo.

Superti, F. F. (1991). Il bilancio di esercizio italiano secondo le normative italiane. Giuffrè, Milano. 
Superti, F. F. (2015). Riflessioni sulla novella legislativa concernente il falso in bilancio in una prospettiva economico-aziendalistica. Le società n.11.

Taylor, A., \& Goodhart, C. (2006). Procyclicality and volatility in the financial system: the implementation of Basel II and IAS 39. International Monetary Fund.

Testaguzza, A. (2015). Un legislatore severo, ma non troppo: la nuova riforma delle false comunicazioni sociali. Osservatorio sulla Corte di Cassazione.

Viganò, E. (1990). L'impresa e il bilancio europeo. Cedam, Padova.

Walton, P. (2004). IAS 39: where different accounting models collide. European Accounting Association, 1.

Zülch, H., \& Lienau, A. (2004). Bilanzierumg zum Verkauf stehender Iangfristiger Ver-mögenswertee sowie aufgegebener Geschäftsbereiche nach IFRS 5, KoR 11/2004.

\section{Copyrights}

Copyright for this article is retained by the author(s), with first publication rights granted to the journal.

This is an open-access article distributed under the terms and conditions of the Creative Commons Attribution license (http://creativecommons.org/licenses/by/4.0/). 